\title{
Investigating Challenges in Financing Contractors for Public Sector Projects in Ghana
}

\author{
Prince Abrokwa Ofori, Kwadwo Twumasi-Ampofo*, Joseph Agyei Danquah, \\ Ernest Osei-Tutu, Safowaa Osei-Tutu \\ CSIR-Building and Road Research Institute, Kumasi, Ghana \\ Email: poforiabrokwa@gmail.com, *kktwumasi2002@yahoo.co.uk,joedanquah@gmail.com, fasota@yahoo.com
}

How to cite this paper: Ofori, P.A., Twumasi-Ampofo, K., Danquah, J.A., OseiTutu, E. and Osei-Tutu, S. (2017) Investigating Challenges in Financing Contractors for Public Sector Projects in Ghana. Journal of Building Construction and Planning Research, 5, 58-70.

https://doi.org/10.4236/jbcpr.2017.52005

Received: March 19, 2017

Accepted: June 12, 2017

Published: June 15, 2017

Copyright $\odot 2017$ by authors and Scientific Research Publishing Inc. This work is licensed under the Creative Commons Attribution International License (CC BY 4.0).

http://creativecommons.org/licenses/by/4.0/

\begin{abstract}
Contractors working with the Public sector encounter numerous challenges in financing projects in Ghana. The challenges which have persisted over the years are both financial and managerial. This paper seeks to ascertain the extent to which contractors' challenges in acquiring funds to execute public sector projects have been solved. The study involved both qualitative and quantitative methods to ascertain the various strategies the contractors go through to obtain public sector projects focusing on the challenges associated with the project execution. The study revealed that delayed payments and inadequate cash flow on the part of government, lack of credit worthiness and inadequate collateral security from contractors are key determinants to challenges associated with financing public sector projects in Ghana. This paper recommends the establishment of a Construction Development Authority (CDA), within the Ministry of Works and Housing to develop financial plans, policies and laws for this important sector of the economy.
\end{abstract}

\section{Keywords}

Public Sector, Project Financing, Delayed Payments, Performance and Contractor Classification

\section{Introduction}

Contractors in Ghana have encountered many challenges over the years which affect performance and delivery. What is prominent among these challenges is financing contractors for public sector projects. A number of studies have been conducted on the success of projects and factors affecting contractors' performance in Ghana; [1] [2] [3] [4]. However, these studies show poor performance by both large and small scale contractors. Other authors also claim that performance is greatly hindered due to managerial inefficiencies [5] [6] [7]. Most gov- 
ernment contracts are poorly planned in the mist of government's fiscal constraint [8] while managerial issues affect contractor performance [9]. Financing public sector projects continues to play a dominant role in the delivery of infrastructure development in Ghana. Financing is an arrangement to ensure that all demands on an institution for money to support expenditures and repayment of loans that are due can be met [10]. Financing is therefore an attempt to coordinate economic decision making to ensure that all payments are made on goods and services without debts or outstanding payments to be made. The government of Ghana is the main client (Employer) for public sector projects with most funding through the Consolidated Fund, Ghana Education Trust Fund (GET-Fund), National Health Insurance Scheme (NHIS), District Assembly Common Fund, Donor Agencies and International Partners. Public sector projects in Ghana are usually designed and supervised by either private or public consultants who help in the contract documentation, monitoring and evaluation [11]. With interest rate comparatively high at $25.32 \%$ as at January, $2016 \mathrm{BoG}$, [12] coupled with enormous collateral requirements from financial institutions make it extremely difficult for contractors to access loans and therefore rely on informal and ad- hoc financial services. The most prominent constraint faced by contractors in Ghana is the difficulty in obtaining funds for the acquisition of construction equipment which form the basis of collateral for project financing. For example, in United States of America (USA), the financial growth rate of construction firms is exactly related to the quantum of collateral that a company can produce when seeking for funds [13]. There have been difficulties in acquiring funds, especially, bank loans in Ghana which have been a major setback to the development of small-scale businesses in developing countries [14]. The success of obtaining loans largely depends on the conditions of contract, conditions of the local financial market and the degree to which the design of the arrangements is adapted to the local circumstances [15]. Contractors eligible to execute projects in the public sector must first be registered with the Registrar General Department and also be of good standing in terms of personnel, equipment and fulfillment of all tax obligations. According to the Ministry of Works and Housing (MWH) [16], contractors are selected for specific projects based on their classifications for building and civil works. The classification register is solely for the use of Government Ministries, Departments, Agencies and Corporations, National, Regional, Metropolitan, Municipal and District Tender Boards and other Institutions which require the services of Building and Civil Contractors for the execution of projects. The Classification exercise aims at the proper grading of contractors into categories and financial classes (i.e. D1/K1, D2/K2, $\mathrm{D} 3 / \mathrm{K} 3$ and $\mathrm{D} 4 / \mathrm{K} 4$ ) with K1D1 being the highest on the classification scale. The aim of this study is to ascertain the extent to which contractors' challenges in acquiring funds to execute public sector projects have been solved.

\section{Literature Review}

Performance is the behavioral competencies to achieving the goals of project- 
based organizations [17]. The definition suggests that performance entails the output and outcome of all activities of an organization in relation to the organization's set goals and objectives. The performance of the public sector contracts in relation to effective and efficient financing of public sector projects has been the challenge of the sector over a period with successive governments. The potential reasons for construction delays of public projects has been due to untimely honoring of certificate by client, credit inaccessibility by contractors and price fluctuations [2]. Badu et al. [18] confirmed this by stating that both large and small-scale contractors experience difficulty in accessing funds. It is enshrined in the general public contract conditions of the Public Procurement Authority (PPA) [19], that certificates be honored within 28 days of issuance of a claim but this barely happens especially with contracts involving local contractors. It is therefore difficult for local contractors to compete with foreign firms both in terms of financial and material resources and as a result fail to win most of the major projects in Ghana [20]. Also, the contractors revealed challenges such as delayed payments by government, inadequate cash flow, change of government, and bureaucratic processes involved in acquiring funds from financial institutions hinder the successful execution of public sector projects leading to eventual abandonment of projects [21]. Memon et al. [22] claim that payment difficulties are a major issue confronting contractors in construction projects, causing delays and a consequent cost overrun. Access to credit, a lack of capacity to compete with foreign contractors, low technology, poor project preparation and contracts awarded based on political considerations had the greatest effects on the performance of Ghanaian contractors [23]. Major factors affecting contractor performance is cash flow among others [24].

Every construction project needs to be regularly financed for its successful completion. Most common sources of funding for construction projects are as follows: Firstly, through trade credit where a contractor receives credit from a supplier of goods in the normal course of business. In practice, the contractor does not have to pay cash immediately for material purchase to be made. A supplier sends goods to the contractor on credit, which the contractor accepts and therefore agrees to pay the amount due on a future date. Trade credit is a spontaneous source of financing, easily available and flexible [25]. This source of funding is largely dependent on the personal relationship between the contractor and the supplier. Secondly, accrued expenses is another spontaneous source of short term financing and is a natural source as it allows the contractor to receive services before paying for them. This represents spontaneous, interest-free source of financing. Thirdly, deferred income is when the contractor receives funds for the services he has agreed to supply in the future. These receipts increase the contactors' liquidity in the form of cash. This advance payment made by clients constitutes the main item of deferred income [25]. Finally, Bank borrowing is when construction firms borrow from banks, which happens to be the main institutional source of working capital finance. Contractors receive funds in the form of overdraft, cash credit, and discount of invoices, letters of credit 
and working capital loans. After trade credit, bank credit is the most important source of working capital requirements for contractors. As reported by the American Institute of Architects, [26], funding problems have been the primary factors stalling commercial real estate construction. There was cancellation of many construction project contracts at the beginning of the economic recession in 2008 due to lack of funding [27]. The Immigrant Investment Program (EB-5) was set up in 1990 to help stabilize the economy of the USA through job creation and capital investment by foreign investors. Construction Investors benefited as this provided them a source of funding and succeeding or remaining on the sidelines. Sewalk et al., [27] further state that, although there are benefits to the EB-5 program, industrial projects proved rather challenging, especially high-tech projects that employ few people. Deloitte, [28] suggests that government should investigate into mechanisms to stimulate market interest and make infrastructure asset more attractive so that a relatively small investment by government (for example through co-funding or a guarantee) could leverage into a much larger increase in total financing as private sector financing is increased by a multiple of government investment in the United Kingdom (UK). Under co-funding, government provides a proportion of about $50 \%$ of the total funding requirement as loan at a low rate of interest reflecting the government's cheaper cost of funding. This by Deloitte, a UK private company, is advantageous since it reduces cost of funding and increases the pool of funding available; financing large projects and involve government lender to encourage additional finance as the market is more confident in the projects. In the United States, as public budgets continue to tighten at all levels of government, innovative financing is becoming increasingly important. In September, 2014, a U.S. department of the Treasury, office of the economic policy, reported an alternative financing which include Public Private Partnership (PPP), the Transportation Infrastructure Finance and Innovation Act (TIFIA), bonds (such as Build America Bonds), tax-exempt qualified private activity bonds (PABs), and credit enhancement. Nesan, [13] reported that, critical factors responsible for increased rate of business failures among the small contractors in the United States include; liability of newness, smallness and adolescence, pace of growth, and unplanned regional growth. Nesan [13] further explains that the line of credit system predominates construction financing and that collateral intensive of companies become the commonality among them when they seek for fund. Cushman et al., [29] make mention of refinancing, mortgage, and transaction loans as other forms of credit supports.

Financial Institutions in Ghana usually request documents from contractors as evidence before granting any form of support. These documents include contract award letter, contract document, letter of undertaking, audited accounts, management structure, source of funding, size of the project and collateral property. Most importantly is the financial standing and Ministry classification. In Ghana, two main ministries are responsible for public construction namely; Ministry of Works and Housing (MWH) and Ministry of Roads and Highways 
(MRH). Eligible contractors are classified under either ministries. They classify the construction firms from K1D1 to K4D4 where K1D1 is the highest classification level eligible for large contracts while K4D4 is the minimum level eligible for small contracts. There is a direct connection between financial institution and the construction industry. The issue of funding cannot be left out in the operation of a construction company in every country. Each party has a role to play in ensuring a successful completion of construction projects. Commercial banks are mostly seen to be collaborative with contractors so that, they are mentioned frequently in signing of contracts. Kibodyo, [30] agrees that some of the most common internal problems attributed to liquidity in construction firms are poor cash flow. Most of these contractors in Ghana have been classified under Small and Medium Scale Enterprise (SME) category of businesses. One of the most pressing challenges of SMEs is obtaining the working capital required for projects [31]. Where collateral security and other documents are available to secure loans, there is a further inhibition of high interest rates. It is very difficult for small scale contractors to work on several projects simultaneously due to unavailability of funds [32]. Some factors considered critically which includes liability of newness, smallness and unplanned regional growth could be held responsible for the increased rate of business failures among construction firms [30]. To handle these factors effectively, appropriate construction financing system needs to be instituted for small scale firms so that, the liabilities and risks associated with them can be efficiently addressed.

It is worth noting that the construction industry is very important as it contributes between 5\% and 10\% of most countries GDP including Ghana [4]. Its contribution to GDP has shown an increasing trend from $8.5 \%$ to $11.8 \%$ from 2010 to 2013 respectively and various attempts have been made to boost this sector over the years. Some of the solutions include the establishment of financial institutions to sustain the construction sector. For instance, the Bank for Housing and Construction (BHC) and the First Ghana Building Society were established to fund and support contractors and other players in the construction industry between 1957 and 1987. These outfits, before they were closed down by government in 2000 due to liquidation, sought to mobilise savings for project financing. The Supreme Military Council I (SMC I) regime financed the LowCost Housing project in the 1970s. This led to establishment of estate housing in some districts and regional capitals [33]. The structural adjustment programme in 1983 saw the formation of a national housing policy committee. This committee had, as part of its mandate, to find alternatives in solving the problems associated with public project financing. There still exists a huge infrastructure gap despite various attempts by successive governments. To close this infrastructure gap, the government of Ghana has since 2001, encouraged Build-OwnOperate and Transfer (BOOT) system through Public-Private Partnership (PPP) [34]; where a private entrepreneur finances public projects, operate/own for an agreed period of time and transfer it to the government upon expiry of the period as has been the case with the provision of students' accommodation in pub- 
lic universities. These BOOT system of financing has been a success in the student hostel projects. On the other hand, institutions such as Building and Road Research Institution of the Council for Scientific and Industrial Research (CSIRBRRI) and Construction Industry Development Institute (CIDI) has been established to research and offer strategic leadership respectively to the built environment. Clearly all these attempts need to be well coordinated by an apex body to provide funding, and regulate activities of this sector of the economy and relieve the Ministry of Water, Resources, Works and Housing (MWRWH) from its numerous functions. Examples elsewhere, of such apex bodies are as stated by Ofori [4], as follows: Ministries of Construction in China and Vietnam, the National Construction Council in Tanzania, the Construction Industry Development Board in Singapore and the Construction Industry Development Council of India. These agencies manage and fund construction firms and organsations dedicated to the continuous development of the industry.

\section{Methodology}

\subsection{Study Area}

The study was conducted within the Kumasi Metropolitan area which is one of the thirty (35) districts in Ashanti Region, Ghana. It is located between Latitude $6.35^{\circ} \mathrm{N}$ and $6.40^{\circ} \mathrm{S}$ and Longitude $1.30^{\circ} \mathrm{W}$ and $1.35^{\circ} \mathrm{E}$ and elevated 250 to 300 meters above sea level. It is approximately $270 \mathrm{~km}$ north of the national capital, Accra. Kumasi, the second largest city, in Ghana and is the administrative capital of the Ashanti region of Ghana. It is a centrally located nodal city with high concentration of economic activities and an annual population growth rate of 5.4\% (KMA, 2017). The respondents for the study are located in suburbs including Adum, Ahodwo, Asafo, Ashanti New Town, Asokwa, Ayigya, Dichemso, Kwadaso, Patasi, Suame among others.

\subsection{Methods}

This study employs a mixed approach to ascertain the extent to which contractors' challenges in acquiring funds to execute public sector projects have been solved. Data was collected using a combined research approach which includes the review of pertinent literature, interviews and administering of survey questionnaires [35]. The questionnaires are grouped under three sub-headings. The first sub heading inquired as to the contractors' classification and sources of funding. The second sub-heading asked questions about the management challenges the contractors face in financing public sector projects while the third sub-heading asked questions about some financial challenges. The questionnaire used a three-point Likert scale (where 1 represents strongly disagree, 2, neutral and 3 represent strongly agree) to ascertain whether these issues still persist as a challenge to contractors. The level of agreement by a respondent indicates understanding as to the extent to which the challenges have been solved. The results obtained are analyzed using frequency clustered charts and bars [36]. Purposive sampling technique was used to select fifty four contractors within the 
Kumasi Metropolis. 54 contractors were considered for the study but 49 firms representing $90.7 \%$ responded. Data was collected for a period of 20 days. Enumerators targeted owners or management members of the firms making use of drop-off and pick-up method [37]. This allowed respondents the options to either self-complete the questionnaire or interviewed in order to obtain high response rate.

\section{Findings and Discussions}

\subsection{Source of Funding Public Sector Projects}

The survey indicated (Table 1) that, $43 \%$ of the construction firms were classified under K1D1 with 39\% and 18\% remaining classified under K2D2 and K3D3 respectively. This shows that a total majority of $57 \%$ firms were small-scaled and this is evident in the current situation of the construction industry in Ghana as it is dominated by small-scaled firms.

\subsection{Source of Funding}

Table 2 represents the summary of the responses on the "Source of funding" for execution of public projects. The highest ranked factor was the 'difficulty to obtain funds from bank to finance public projects with an average response value of 2.4, followed by pre-financing through internally generated funds (2.3). However, these two highly ranked factors were within the neutral response rate

Table 1. Classification of contractors.

\begin{tabular}{ccc}
\hline Classification & Frequency & Percentage (\%) \\
\hline K1D1 & 21 & 43 \\
K2D2 & 19 & 39 \\
K3D3 & 9 & 18 \\
TOTAL & 49 & 100 \\
\hline
\end{tabular}

Table 2. Source of funding.

\begin{tabular}{l}
\multicolumn{7}{c}{ RANKS } \\
\cline { 2 - 7 } FACTORS \\
\cline { 2 - 6 }
\end{tabular}

Source: Authors' Field Survey, (2017). 
and therefore did not agree. Two other factors including pre-financing through the use of bank credit facilities and low interest rate were not agreed upon with average values of 1.5 and 1.2 respectively.

It is obvious from Table 2 that obtaining funds to finance public sector projects is a challenge which goes a long way to delay the projects and affect performance. This confirms a study by Ofori-Kuragu et al. [6] in which they mention among others, difficulty in accessing credit facilities by contractors. The results show a continuous trend of funding challenges as state earlier by Badu et al. [18]. Internally generated fund (IGF) as a solution to financing public project seems very critical to the respondents. An interview with some of them indicated that investment which could help secure IGF is low due to high operation cost. Moreover, high bank lending (interest) rate as emphasised by Ugochukwu, [32] makes it difficult to generate IGF in the sense that a larger part of their profit is used to service loans if a company manages to obtain one. Lending rate is relatively high at an average $28.11 \%$ per annum making it difficult to access loans from banks in Ghana by the respondents.

\subsection{Managerial Challenges}

Managerial challenges have been spelt out in Table 3. Respondents did not agree on any of the factors with 1.6, 1.9 and 1.9 mean values for "qualified personnel sections", "functional management structure" and "difficulty in documentation for funding" respectively. Only one factor (difficulty in obtaining records) had a mean value of 2.6. The study reveals four factors that make up the managerial challenges including "functional management structure", "qualified personnel handling various sections of the company", "records keeping and documentation". Every credible organization needs a well-structured management system in place to progress. The firm must be able to have a well-defined and organized management structure in place. Respondents, in an interview, agreed that, their management structures are non-existent and therefore encounter challenge in financing public sector projects, claiming that the most companies (D2/K2,

Table 3. Managerial challenges.

\begin{tabular}{|c|c|c|c|c|c|c|c|}
\hline \multirow[b]{2}{*}{ FACTORS } & \multicolumn{3}{|c|}{ RANKS } & \multirow[b]{2}{*}{$\begin{array}{l}\text { Sum } \\
(\mathrm{N})\end{array}$} & \multirow[b]{2}{*}{$\Sigma \mathrm{W}$} & \multirow[b]{2}{*}{ Mean } & \multirow[b]{2}{*}{ Rank } \\
\hline & 1 & 2 & 3 & & & & \\
\hline $\begin{array}{c}\text { Your company has a } \\
\text { functional management } \\
\text { structure }\end{array}$ & 23 & 6 & 20 & 49 & 95 & 1.9 & 2 \\
\hline $\begin{array}{l}\text { Records on projects are } \\
\text { difficult to obtain }\end{array}$ & 9 & 3 & 37 & 49 & 126 & 2.6 & 1 \\
\hline $\begin{array}{c}\text { Every section is headed by a } \\
\text { qualified personnel }\end{array}$ & 31 & 6 & 12 & 49 & 79 & 1.6 & 4 \\
\hline $\begin{array}{l}\text { Preparing documents for } \\
\text { funding is difficult }\end{array}$ & 21 & 10 & 18 & 49 & 95 & 1.9 & 2 \\
\hline
\end{tabular}

Source: Authors' field survey, (2017). 
D3/K3) are managed by the Chief executive officer without permanent administrators and accountants. Respondents claimed that lack of proper documentation is a challenge to the firms' acquisition of funds for public projects. This confirms studies by Ahadzie and Amoah-Mensah [7] that most contractors fail to obtain financial assistance due to poor managerial practices. Local contractors require technical training as well as assistance in business management and contracting procedures in order to strengthen capacity of small scale firms in the construction industry Deelen and Bonsu [15]. Moreover, this confirms Laryea [20] study which highlighted difficulty in obtaining qualified personnel by contractors. It is therefore not surprising to realize the establishment of the National Artisan Training Centre in Kumasi by the Building and Road Research Institute to train personnel for contractors.

\subsection{Financial Challenges}

Summary of the responses on the "financial challenges" for execution of public projects is shown in Table 4. The highest ranked factor was the "delays in honouring certificates" with an average response value of 2.7 , followed by difficulty to meet collateral requirements for loans with a mean value of 2.6 and savings with more than one bank (2.0). Continuous cash flow for projects was the lowest ranked with an average of 1.8 which indicates respondents' disagreement with this factor. Similarly, the three highly ranked factors were within the neutral response rate and therefore not agreed upon. Respondents agreed that, delayed payments (honouring of certificates) on the part of Government (The Employer) is a significant hindrance to financing public sector projects even though some contract documents available indicate up to 90 days for employers to honour certificates. The study revealed some reasons for delayed payments to include poor planning and bureaucracy on the part of the employer. This confirms earlier studies by Fugah and Agyarkwa [2] and Badu et al. [18] about untimely payment of certificate by clients. The survey indicated that cash flow is a major challenge based on the contractors experience in an interview. Table 4 shows

Table 4. Financial challenges.

\begin{tabular}{|c|c|c|c|c|c|c|c|}
\hline \multirow[b]{2}{*}{ FACTORS } & \multicolumn{3}{|c|}{ RANKS } & \multirow[b]{2}{*}{$\begin{array}{l}\text { Sum } \\
(\mathrm{N})\end{array}$} & \multirow[b]{2}{*}{$\Sigma \mathrm{W}$} & \multirow[b]{2}{*}{ Mean } & \multirow[b]{2}{*}{ Rank } \\
\hline & 1 & 2 & 3 & & & & \\
\hline $\begin{array}{c}\text { There are delays in honouring } \\
\text { of certificates }\end{array}$ & 4 & 5 & 40 & 49 & 134 & 2.7 & 1 \\
\hline $\begin{array}{l}\text { Cash flow for public projects } \\
\text { is continuous }\end{array}$ & 24 & 9 & 16 & 49 & 90 & 1.8 & 4 \\
\hline $\begin{array}{l}\text { It is prudent to save with } \\
\text { more than one bank }\end{array}$ & 24 & 3 & 22 & 49 & 96 & 2.0 & 3 \\
\hline $\begin{array}{l}\text { It is difficult to meet collateral } \\
\text { requirements for loans }\end{array}$ & 7 & 4 & 38 & 49 & 129 & 2.6 & 2 \\
\hline
\end{tabular}

Source: Authors' field survey, (2017). 
that respondents agreed that poor cash flow from contractors is a challenge facing contractors financing public sector projects. As stated by Kibodyo, [30] some of the most common internal problems attributed to liquidity in construction firms is poor cash flow. Akomah and Jackson [24] reiterated that major factors affecting contractor performance is cash flow. Furthermore, savings habits (savings with more than one bank) with the aim of taking advantage of different financial products simultaneously as revealed in an interview is seemingly, not prudent. This survey again brings to light inadequate collateral security as a major challenge in obtaining funds from financial institutions for public sector projects. An interview with respondents indicated that it is difficult to procure equipment to serve as collateral due to high import levies and taxes.

\section{Conclusions and Recommendations}

Majority of the sampled public sector contractors were small-scaled in nature. Contractors in Ghana continue to experience financial and managerial challenges and not much has been done to solve these challenges. At the design stage of a public project, an assessment has to be made for possible ways to finance the public sector projects contractors. Negotiations with private partner institutions have to start at an early stage to allow the institutions enough time to peruse the legal and financial details. Government and her agencies (Employers) must ensure prompt honoring of certificates as enshrined in the contract conditions. Regular and timely payment will eventually help contractors to service loans obtained from financial institutions and ultimately boost contractors' credit worthiness.

The study recommends that credit worthiness of contractors, in terms of materials and equipment procurement, could be enhanced if they are allowed to import with a tax waiver to help maintain and increase good equipment standing of contractors. Qualified construction professionals should be employed by construction companies to aid in carrying out proper planning towards a successful project. Employees already employed need further training to ensure better management of the firms. Government should also ensure timely honoring of certificates for contractors to complete projects on time; adequate financial standing of government for construction works is significant in honoring certificates to contractors to maintain constant cash flow throughout the entire duration of the construction. Private Sector should continue to partner government in order to generate adequate funds for timely completion of projects through PPPs. Ultimately, this paper recommends the formation of a Construction Development Authority (CDA), within the Ministry of Works and Housing to develop financial plans for public projects, policies and laws to improve this important sector of the economy.

\section{Acknowledgements}

Authors are particularly grateful to Emmanuel Ampofo Twumasi, and Sampson Kusi, National Service Personnel for their assistance in the data collection exercise. 


\section{References}

[1] Ahadzie, D.K. (1995) Factors Affecting Labour Productivity in the Construction Industry in Ghana: The Perception of Consultants and Contractors. Journal of the Building and Road Research Institute, 3, 22-32.

[2] Fugar, F.D.K. and Agyarkwa, A.B. (2010) Delays in Building Construction in Ghana. Australian Journal of Construction Economics and Building, 10, 103-116.

[3] Amoah, P., Ahadzie, D.K. and Danso, A. (2011) The Factors Affecting Construction Performance in Ghana: The Perspective of Small-Scale Building Contractors. The Surveyor Journal, 4, 41-48.

[4] Ofori, G. (2012) Developing the Construction Industry in Ghana: The Case for Central Agency. National University of Singapore, Singapore.

[5] Edmonds, G.A. and Miles, D.W.J. (1984) Foundations for Change: Aspect of the Construction Industry in Developing Countries. ITG Publications, UK. https://doi.org/10.3362/9781780442242

[6] Konadu-Agyemang (2001) A Survey of Housing Conditions \& Characteristics in Accra, an African City. Habitat International, 25, 15-34. https://doi.org/10.1016/S0197-3975(00)00016-3

[7] Ahadzie, D.K. and Amoah-Mensah, K. (2008) Management Practices in Ghanaian House Building Industry. Journal of Science and Technology, 30, 62-75.

[8] Asiedu, R.O. and Alfen, H.W. (2015) Understanding the Underlying Reasons behind Time Overruns of Government Building Projects in Ghana. KSCE Journal of Civil Engineering, 1-9.

[9] Addo, J.N.T. (2015) Delay and Its Effect on the Delivery of Construction Projects in Ghana. African Journal of Applied Research, 1, 236-246.

[10] Kessey, K.D. (1995) Financing Local Development in Ghana: Mobilization and Management of Fiscal Resources in Kumasi Metropolis. Dortmund Spring Research Series 12.

[11] Dadzie, J., Abdul-Aziz, A.R. and Kwame, A. (2012) Performance of Consultants on Government Projects in Ghana: Client and Contractor Perspective. International Journal of Business and Social Research, 2, 256-267.

[12] Bank of Ghana (2016) Markets/Interbank Interest Rates/Daily Interest Rates. https://www.bog.gov.gh/index.php?option=com_wrapper\&view=wrapper\&Itemid= $\underline{255}$

[13] Nesan, L.J. (2012) Project Finance Model for Small Contractors in USA. Australian Journal of Construction Economics and Building, 16, 25. https://doi.org/10.5130/ajceb.v6i1.2966

[14] Eyiah, A.K. (2001) An Integrated Approach to Financing Small Contractors in Developing Countries: A Conceptual Model. In: Construction Management and Economics, Routledge, London, 511-518. https://doi.org/10.1080/01446193.2001.9709627

[15] Deelen, L. and Bonsu, K. (2002) Equipment Finance for Small Contractors in Public work Programmes. Employment Sector, International Labour Office, Route des Morillons, Geneva.

[16] Ministry of Water Resources, Works and Housing (MWRWH) (2014) Guidelines for the Classification of Contractors. http://www.mwrwh.gov.gh/index.php/classification

[17] Ahadzie, D.K. (2008) A Model for Predicting the Performance of Project Managers in Mass Housing Building Projects in Ghana. PhD Thesis, School of Engineering 
and Built Environment, Wolverhampton University, Wolverhampton.

[18] Badu, E., Edwards, D.J., Owusu-Manu, D. and Brown, D.M. (2012) Barriers to the Implementation of Innovative Financing (IF) of Infrastructure. Journal of Financial Management of Property and Construction, 17, 253-273. https://doi.org/10.1108/13664381211274362

[19] Public Procurement Authority, Act 663 (2003) Tender Documents for Procurement of Works, Small Contracts, (Small Value, Short Duration and Low Risk).

[20] Laryea, S. (2010) Challenges and Opportunities Facing Contractors in Ghana. Proceedings of West Africa Built Environment Research (WABER) Conference, Accra, 27-28 July 2010, 215-226.

[21] Twumasi-Ampofo, K., Osei-Tutu, E., Decardi-Nelson, I. and Abrokwa Ofori, P. (2012) A Model for Reactivating Abandoned Public Housing Projects in Ghana. Journal of Civil and Environmental Research, 6, 6-16. www.iiste.org

[22] Memon, A.H., Rahman, I.A., Abdullah, M.R. and Azis, A.A.A. (2014) Factors Affecting Construction Cost Performance in Project Management Projects: Case of MARA Large Projects. International Journal of Civil Engineering and Built Environment, 1, 30-35.

[23] Ofori-Kuragu, J.K., Baiden, B. and Badu, E. (2014) Factors Affecting Ghanaian Contractor Performance. Proceedings of the W107 Conference: Construction in Developing Countries and Its Contribution to Sustainable Development, Lagos, 28-30 January 2014.

[24] Akomah, B.B. and Jackson, E.N. (2015) Factors Affecting the Performance of Contractors on Building Construction Projects: Central Region, Ghana. International Journal of Innovative Research \& Development, 5, 151-158.

[25] Rameezdeen, R., Palliyaguru, R.S. and Amaratunga, D. (2006) Financing Contractors in Development Countries: Impact of Mobilization Advance Payment. Department of Building Economics, University of Moratuwa, Moratuwa and Research Institute for the Built and Human Environment, University of Salford, Salford.

[26] The American Institute of Architects (2011) Stalled Construction Projects and Financing (An Agenda to Keep Construction of American's Buildings and Infrastructure Going). https://www.construction.com/PDFs/2011/AIA-Stalled-Project-Report.pdf

[27] Sewalk, S., Wang, Y., Knox, K. and Fang, Y. (2013) Financing Construction Projects Using the EB-5 Program. 49th ASC Annual International Conference Proceedings, San Luis Obispo, 9-13 April 2013.

[28] Deloitte (2013) Funding Options, Alternative Financing for Infrastructure Development. Sidney, Australia. www.deloitte.com.au

[29] Cushman, R.F. and Bigda, J.P. (1985) Construction Business Handbook: A Practical Guide to Accounting, Credit, Finance, Insurance and Law for the Construction Industry. McGraw Hill, New York.

[30] Kibodyo, F.G. (2008) Financing Solution to Contracting Industry Challenges. Consultative Meeting on Contractors Financial Management Aspects, Dar es Salaam, 8-9 May 2008.

[31] Donkor, D.K., Hananu, B. and Aninyie, P. (2014) Financing Small Scale Contractors through Mobilization Advance Payment for Improved Performance: The Case of the Tamale Metropolis. International Journal of Engineering Research and Applications, 4, 97-103.

[32] Ugochukwu, S.C.O.T. (2014) Participation of Indigenous Contractors in Nigerian Public Secto Construction Project Managing Working Capital Projects and Their 
Challenges in Nigeria. International Journal of Civil Engineering, Construction and Estate Management, 1, 1-21.

[33] Songsore, J. (2003) The Urban Housing Crisis in Ghana: Capital, the State versus the People. Ghana Social Science Journal, 2, 1-31.

[34] Hagan, T. (2009) Ghana: Funding Infrastructure by Public Private Partnerships (PPP).

[35] Ameyaw, C., Mensah, S. and Osei-Tutu, E. (2012) Public Procurement in Ghana: The Implementation Challenges to the Public Procurement Law 2003 (Act 663). International Journal of Construction Supply Chain Management, 2, 55-65. https://doi.org/10.14424/ijcscm201012-55-65

[36] Boone, H.N. and Boone, D.A. (2012) Analyzing Likert Data. The Journal of Extension, 50, 1-5. https://joe.org/joe/2012april/tt2.php

[37] Allred, S.B. and Ross-Davis, A. (2010) The Drop-Off and Pick-Up Method: An Approach to Reduce Non-Response Bias in Natural Resource. Small-scale Forestry. Springer, Berlin.

http://static1.1.sqspcdn.com/static/f/543796/15756573/1325012565467/DOPU+Met hodSSF_2011.pdf?token=6BNwGYJlAIkj6SeYFakIjQK6apg\%3D

Submit or recommend next manuscript to SCIRP and we will provide best service for you:

Accepting pre-submission inquiries through Email, Facebook, LinkedIn, Twitter, etc. A wide selection of journals (inclusive of 9 subjects, more than 200 journals) Providing 24-hour high-quality service User-friendly online submission system Fair and swift peer-review system Efficient typesetting and proofreading procedure Display of the result of downloads and visits, as well as the number of cited articles Maximum dissemination of your research work

Submit your manuscript at: http://papersubmission.scirp.org/ Or contact jbcpr@scirp.org 